\title{
The type III secretion system is necessary for the development of a pathogenic and endophytic interaction between Herbaspirillum rubrisubalbicans and Poaceae
}

\author{
Maria Augusta Schmidt', Eduardo Balsanelli', Hellison Faoro ${ }^{1}$, Leonardo M Cruz ${ }^{1}$, Roseli Wassem², \\ Valter A de Baura', Vinícius Weiss', Marshall G Yates ${ }^{1}$, Humberto M F Madeira ${ }^{3}$, Lilian Pereira-Ferrari', \\ Maria H P Fungaro ${ }^{4}$, Francine M de Paula ${ }^{4}$, Luiz F P Pereira ${ }^{5}$, Luiz G E Vieira ${ }^{5}$, Fábio L Olivares ${ }^{6}$, Fábio O Pedrosa ${ }^{1}$, \\ Emanuel M de Souza ${ }^{1}$ and Rose A Monteiro ${ }^{1 *}$
}

\begin{abstract}
Background: Herbaspirillum rubrisubalbicans was first identified as a bacterial plant pathogen, causing the mottled stripe disease in sugarcane. H. rubrisubalbicans can also associate with various plants of economic interest in a non pathogenic manner.

Results: A 21 kb DNA region of the H. rubrisubalbicans genome contains a cluster of 26 hrp/hrc genes encoding for the type three secretion system (T3SS) proteins. To investigate the contribution of T3SS to the plant-bacterial interaction process we generated mutant strains of $\mathrm{H}$. rubrisubalbicans M1 carrying a Tn5 insertion in both the hrcN and hrpE genes. H. rubrisulbalbicans hrpE and hrcN mutant strains of the T3SS system failed to cause the mottled stripe disease in the sugarcane susceptible variety B-4362. These mutant strains also did not produce lesions on Vigna unguiculata leaves. Oryza sativa and Zea mays colonization experiments showed that mutations in hrpE and hrcN genes reduced the capacity of H. rubrisulbalbicans to colonize these plants, suggesting that hrpE and hrcN genes are involved in the endophytic colonization.
\end{abstract}

Conclusions: Our results indicate that the T3SS of $\mathrm{H}$. rubrisubalbicans is necessary for the development of the mottled stripe disease and endophytic colonization of rice.

\section{Background}

Herbaspirillum rubrisubalbicans was originally described as the causal agent of mottled stripe disease in sugarcane (Saccharum oficinarum) but it can also cause red stripe disease in some varieties of sorghum (Sorghum bicolor) [15]. The mottled stripe disease was first described in Louisiana (USA) in 1932 and is characterized by the development of red streaks with white spots on the leaves of sugarcane. It is a disease of relatively small economic importance and affects sugarcane varieties B-4362 and

\footnotetext{
* Correspondence: roseadele@ufpr.br

'Department of Biochemistry and Molecular Biology, Universidade Federal do Paraná, R. Francisco H. dos Santos s/n, Curitiba 81531-990, Brazil Full list of author information is available at the end of the article
}

Taiwang [3,6,7]. Inoculation with high numbers of $H$. rubrisubalbicans cells in the stems of the susceptible varieties cause typical symptoms of the disease. The point of injection becomes red and necrotic and, after seven days, red stripes are formed along the vessels near the inoculation site, accompanied by different degrees of chlorosis. At this stage the bacteria infest the protoxylem and the metaxylem of the leaves. On the twentieth day the bacteria block both xylem lumen and there is necrosis around the inoculation point [1]. The extensive bacterial colonization results in the expansion of intercellular spaces and subsequent compression of the host plant cells. Bacterial cells can eventually move from the vessels into the surrounding mesophyll, reaching the stomata and reducing the

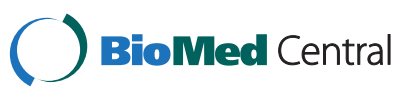


photosynthetic activity and lifetime of the leaves. Host plant responds with the production of phenolic compounds, gum, and localized cell death [1].

H.rubrisubalbicans can cause symptoms of red stripe disease on sorghum leaves of some cultivars after artificial inoculation. This mild disease is characterized by red stripes along the veins of the leaves near the point of inoculation, and these leaves showed dense colonization by $H$. rubrisubalbicans at 5 days after inoculation. $H$. rubrisubalbicans is restricted to the metaxylem, protoxylem and associated lacunae, which are completely filled with bacteria; this behavior is different from that observed in mottled stripe disease, where the bacteria escaped from the vascular system to the adjacent mesophyll and substomatal cavities destroying chroplasts, and revealing the mottled background $[1,5]$.

H. rubrisubalbicans is also known as a PGPR (Plant Growth-Promoting Rhizobacteria). This bacterium is a component of the bacterial consortium developed by the Brazilian Agricultural Research Company (EMBRAPA) and recommended as a commercial inoculant for sugarcane [8-10].

The genes of the type three secretion system (T3SS) were first identified as hypersensitivity response and pathogenicity $(h r p)$ genes in the phytopathogenic bacterium Pseudomonas syringae by Lindgren et al. [10]. Subsequent studies showed that the hrp genes of $P$. syringae were located in a cluster of $25 \mathrm{~Kb}$. Similar gene clusters were also found in other phytopathogenic organisms [11-13]. Several hypersensitive response and pathogenicity genes of plant pathogens are homologous to genes of animal pathogens that encode components of the T3SS [14,15], and were named $h r c$ (HR conserved) [16]. The T3SS is present in Gram-negative pathogens of animals and plants, and was then described in symbiotic [17], saprophytic and associative bacteria [18-20]. The T3SS consists of a secretion apparatus that delivers a series of effector proteins [21] across the inner membrane, the periplasmic space and outer membrane of bacteria into the eukaryotic cell cytoplasm. The effector proteins manipulate and control the host cell metabolism to the advantage of the pathogen and to repress defense mechanisms. Analyses of a partial genome sequence of $H$. rubrisubalbicans revealed the presence of genes homologous to the T3SS. In this work we show that $H$. rubrisubalbicans T3SS is necessary for the development of the mottled stripe disease in sugar cane and also for endophytic colonization of rice.

\section{Results}

\section{Organization of the $h r p / h r c$ gene cluster in $H$.} rubrisubalbicans M1

The hrp/hrc genes cluster of $H$. rubrisubalbicans M1 contains 26 genes distributed in a $21 \mathrm{~kb}$ region, composed of seven $h r p$, eight $h r c$, and eleven genes encoding for hypothetical proteins (GenBank accession JN256203) (Figure 1). Based on partial homology we found that most of the genes in this cluster encode structural proteins of the T3SS, that are involved in the construction of the base and the injectiossome.

Comparison of the DNA sequence of the hrp/hrc cluster of $H$. seropedicae SmR1 with $H$. rubrisubalbicans showed that the genes are almost identically arranged (Figure 1). However, aminoacid sequence comparison of the proteins encoded by the $h r p / h r c$ genes of both organisms showed that only five out of 26 proteins have more than $70 \%$ identity (Additional file 1: Table S1). The degree of identity between each of the deduced H. rubrisubalbicans hrp/hrc proteins and its counterpart from $H$. seropedicae ranged from 11\% (hypothetical protein 6) to $86 \%(\mathrm{HrcS})$, and the respective similarity varied from 17 to $97 \%$ (Additional file 1: Table S1). The structural organization of hrcUhrcThrcShrcRhrcQ and hrpBhrcJhrpDhrpE genes of H. rubrisubalbicans resembles that of $H$. seropedicae, Pseudomonas syringae, Erwinia amylovora, and Pantoea stewartii (Figure 1). Two genes, $h r p L$ and $h r p G$ (JN256211), which probably encode the regulatory proteins HrpL and HrpG may be responsible for the regulation of T3SS genes. In the region upstream of $h r p L$ no $\sigma^{54}$-dependent promoter was found, in contrast to what was observed in the $h r p L$ promoter region of Pseudomonas syringae pv. maculicola [22,23]. The $h r p L$ gene is located at one end of the hrp/ $h r c$ gene cluster while $h r p G$ is located approximately $10 \mathrm{~kb}$ downstream from the $h r c C$ gene at the other end.

Within the Betaproteobacteria subdivision two groups of T3SS-containing organisms are observed concerning the conservation of gene order in the T3SS gene cluster members of group I include Erwinia sp., Pantoea sp., Pectobacterium sp., and Pseudomonas sp. This group includes only Gammaproteobacteria, thus far, suggesting that it is taxonomically uniform. All members of this group contain the $h r p L$ gene, that encodes a sigma factor. Group II include representants of the Betaproteobacteria such as Ralstonia sp., Burkholderia sp. as well as Gammaproteobacteria, such as Xanthomonas sp. This group lacks $h r p L$ gene but also contains HrpB or HrpX, which are transcriptional regulators of the AraC family [24]. Phylogeny of $h r c N$ gene revealed that those organisms form monophyletic groups (Figure 2). Both $\mathrm{H}$. seropedicae SmR1 and H. rubrisubalbicans M1 contain the hrpL gene and show T3SS gene organization similar to that observed in organisms of the group I. However, the phylogeny of $h r c N$ gene shows that, the two Herbaspirillum species clustered closer but outside from members of the group I- $h r c N$ cluster (Figure 2), suggesting a distant evolutionary relationship and supporting a hybrid system as suggested by Pedrosa et al. [25] for $H$. 


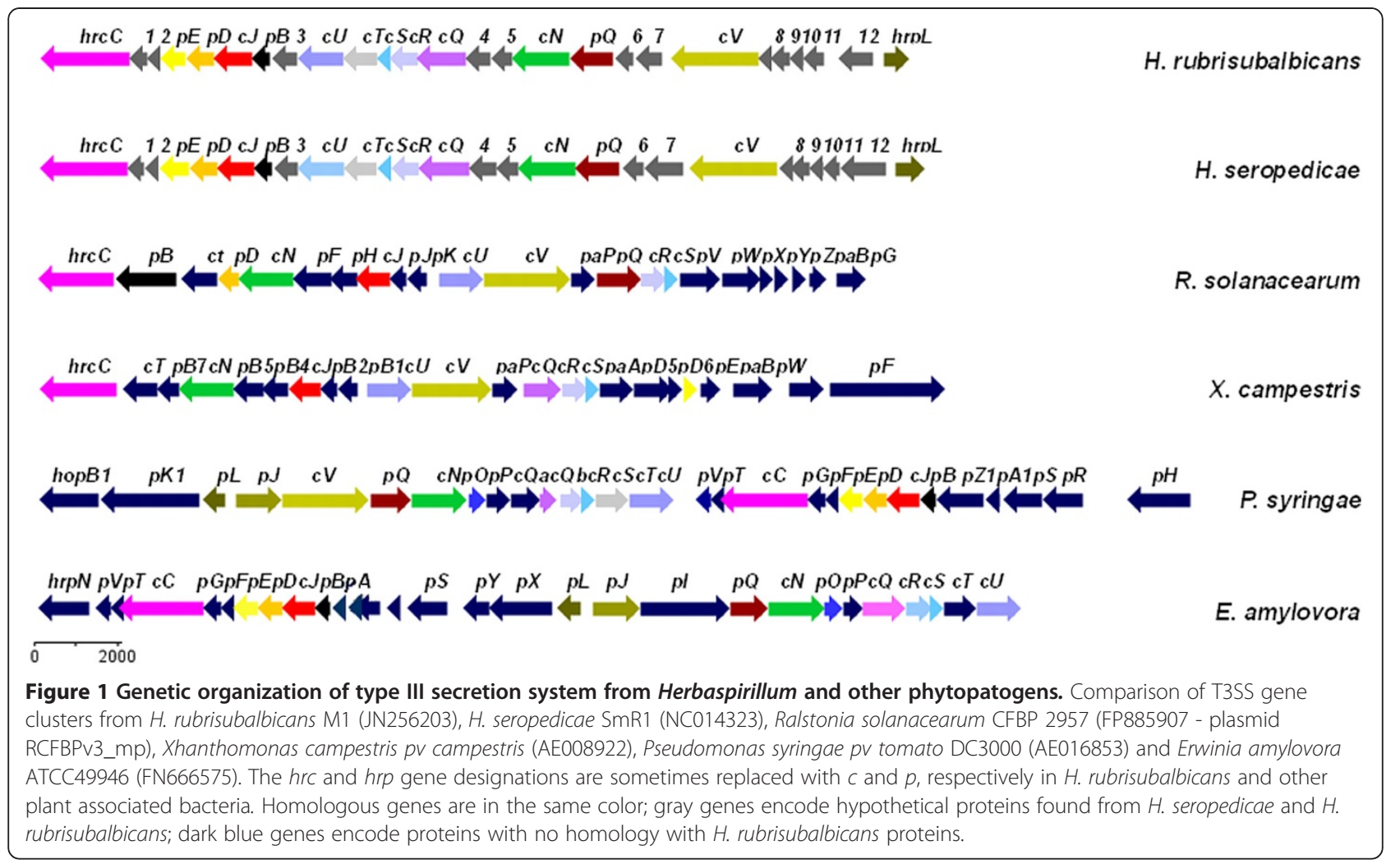

seropedicae SmR1, what may partially explain the differences observed in gene organization and similarity among Herbaspirillum sp. and group I bacteria.

Sequences similar to the HrpL-dependent promoter consensus (GGAACC-N15-CCACTCAAT) [26-29] were detected upstream from orf1, orf6, hrpO, orf8, $h r p B$ and orf10 (Figure 3a, b). The ORFs from orf8 to orf9, from $h r p B$ to $h r p E$ and from orf10 to $h r c C$ overlap or are spaced by less than 94 nucleotides apart, suggesting that these three groups of genes are part of three distinct operons. The ORFs from orf6 to $h r c N$ appear to belong to the same operon, although a $114 \mathrm{bp}$ gap is found between orf6 and orf7, but no promoter was found upstream from orf7. Likewise, the intergenic regions orf1-orf2 and orf3-orf4 contain $336 \mathrm{bp}$ and $249 \mathrm{bp}$, respectively, but no promoter sequence was identified. This analysis suggests that $H$. rubrisubalbicans $h r p / h r c$ genes are probably organized in six HrpL-dependent operons.

\section{H. rubrisubalbicans hrp associated genes}

Two Hrp associated genes called hpaB (JN256204) and hpaB1 (JN256205) encode general T3SS chaperones, which promote secretion and translocation of multiple effectors proteins [30]. The $h p a B$ and $h p a B 1$ genes are predicted to belong to the TIR chaperone protein family. The $h p a B 1$ gene was found approximately $12 \mathrm{~kb}$ downstream from the $h r c C$ gene and it encodes a small acidic chaperone.

\section{H. rubrisubalbicans T3SS effector proteins}

Type III secretion systems have been characterized in a variety of plant pathogenic bacteria. The structural proteins of these systems are highly conserved, but the T3SS effector proteins, that play a central role in virulence, are less conserved and difficult to identify.

A BlastX search of the $H$. rubrisubalbicans partial genome sequence $(30 \%)$ against NCBI-nr database allowed identification of five candidates of $H$. rubrisubalbicans effector proteins HropAN1 (H. rubrisubalbicans outer protein) (JN256208), HropAV1 (JN256209), HropF1 (JN256210), Hrop1 (JN256206) and Hrop2 (JN256207) (Table 1). Hrop1 and Hrop2 were also identified as T3SS effectors by the program EffectiveT3 (http://www.effectors. org/) [31]. The genes encoding these proteins are located apart from the $h r p / h r c$ genes cluster.

The proteins HropAN1 (H. rubrisubalbicans outer protein), HropAV1 and HropF1 are similar in sequence to HopAN1 (Burkholderia sp.), HopAV1 (Ralstonia solanacearum) and XopF1 (Xanthomonas oryzae), respectively. Hrop1 is homologous to a type III effector protein from Ralstonia solanacearum MolK2. Hrop2 belongs to the leucine-rich repeats (LRRs) ribonuclease inhibitor (RI)-like subfamily [32]. The genes encoding HropAV1 and Hrop1 immediately upstream of the hpaB1 gene, and outside the main T3SS gene cluster.

The $H$. rubrisubalbicans $\mathrm{HrpB}$ protein is homologous (identity $27 \% /$ similarity $48 \%$ ) to the Pseudomonas syringae 


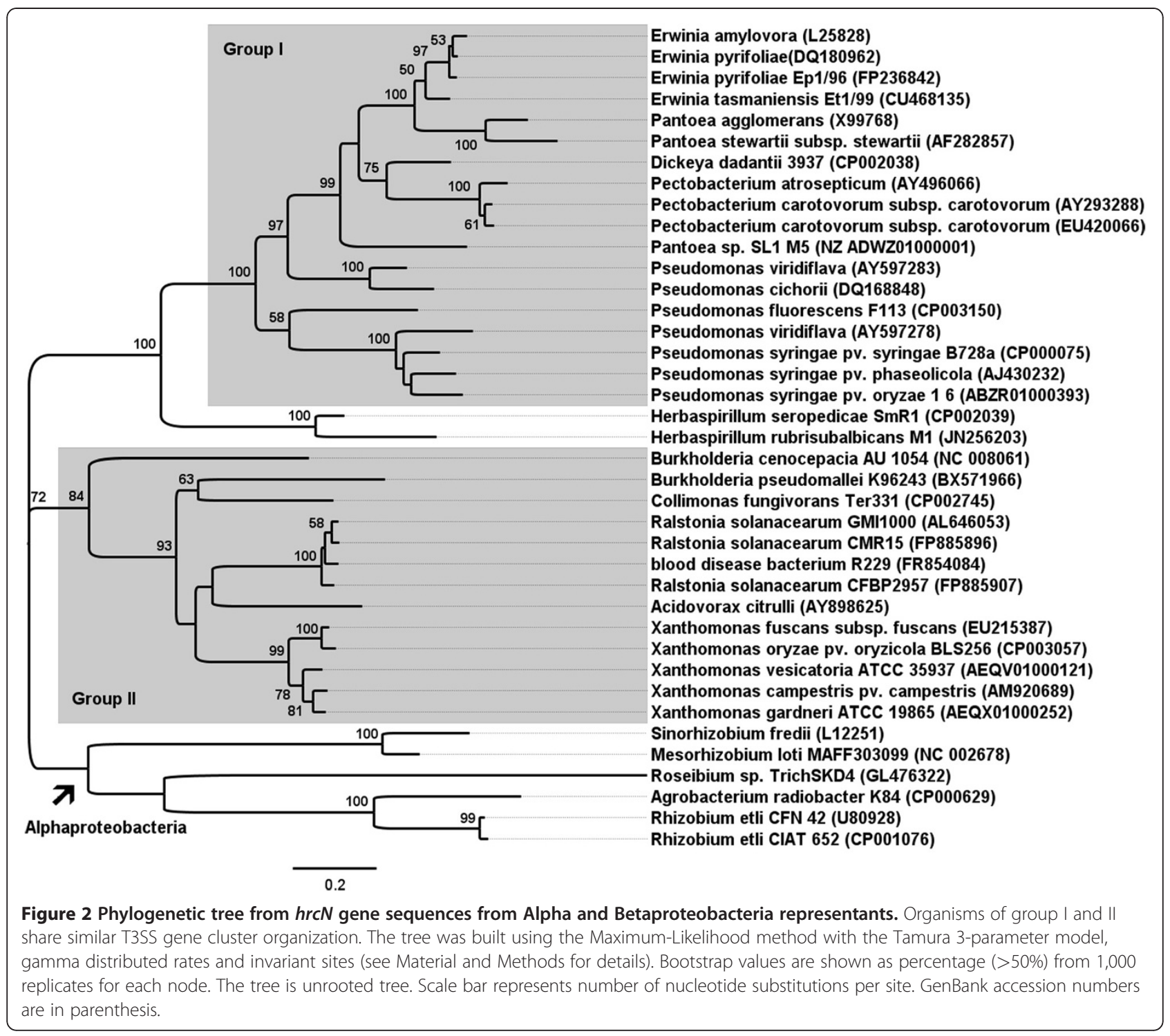

HrpB protein that is secreted and contributes to elicitation of the hypersensitive response in Nicotiana tabacum and Nicotiana benthamiana [33]. This similarity suggests that H. rubrisubalbicans HrpB is a candidate for a secreted protein.

H. rubrisubalbicans $h r p E$ and $h r c N$ genes are essential for the development of mottled stripe disease in sugarcane variety B-4362.

To investigate the contribution of T3SS to the plantbacterial interaction process we generated the mutants TSN and TSE of $H$. rubrisubalbicans carrying Tn5 insertions in the $h r c N$ and $h r p E$ genes, respectively. H. rubrisubalbicans $\mathrm{HrcN}$ protein contains 442 aminoacids and is homologous to T3SS-associated ATPases. The $H$. rubrisulbalbicans HrpE protein contains 202 aminoacids and belongs to the YscL/FliH family of cytoplasmic proteins [34].
The wild type M1 and the mutant strains TSN and TSE were inoculated into the susceptible sugarcane variety B-4362. After 15 days, strain M1 caused typical symptoms of mottled stripe disease (mottled background with red stripes and red patches) and well-developed signs of necrosis in leaves invaded by bacteria (Figure 4a). In contrast, the mutants TSN and TSE did not elicit disease symptoms (Figure $4 \mathrm{~b}, \mathrm{c}$ ). These results indicate that $h r p E$ and $h r c N$ gene products are required for the expression of visible symptoms of mottled stripe disease in sugarcane leaves variety B-4362.

Samples of B-4362 leaves inoculated with the strains M1, TSE and TSN were analyzed by light microscopy (LM) and transmission electron microscopy (TEM). Cross sections of the control leaf did not have any visible symptoms and showed the expected anatomical organization for sugarcane foliar blades (Figure 5a). Detailed 


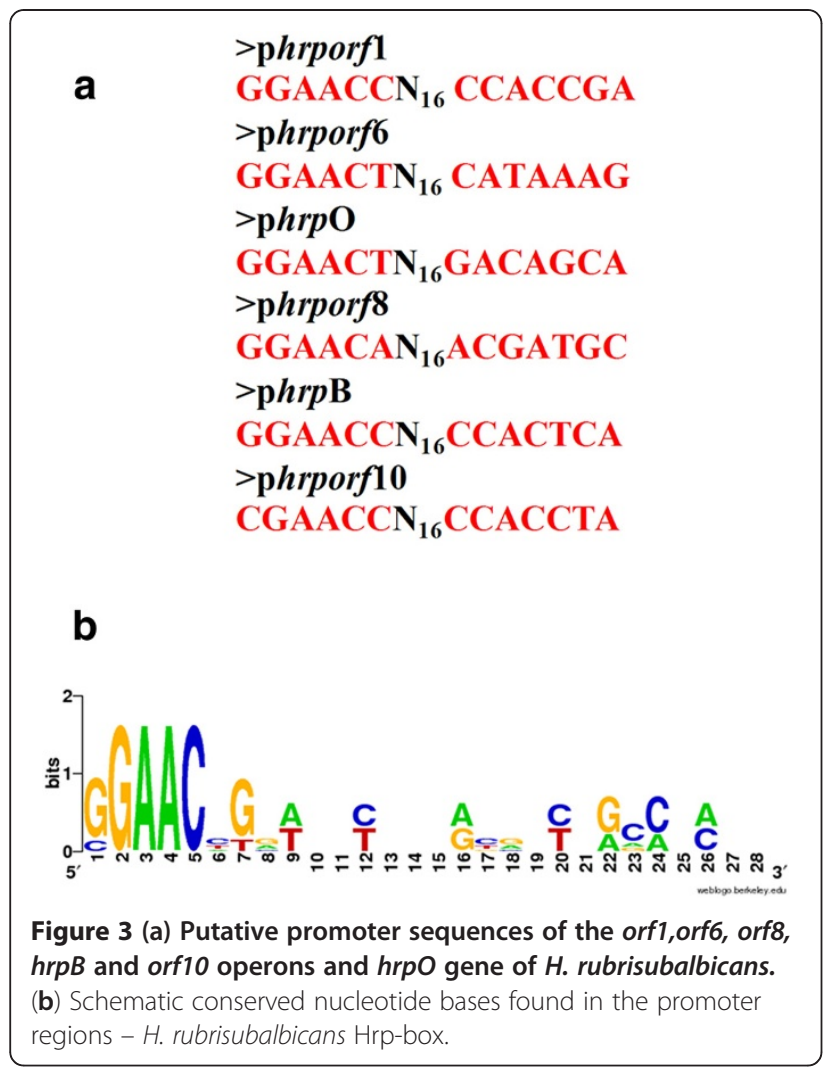

views of the bundle sheath layer showed chloroplasts of regular shape, distribution and appearance (Figure 5b). In contrast, leaf blades developing symptoms of the mottled stripe disease (inoculated with M1) showed disorganization of the parenchyma tissue characterized by cell wall swelling, hypertrophy and degradation of chloroplasts in both the bundle sheath layer and radial mesophyll cells (Figure 5c). These tissue alterations were associated with extensive colonization of the intercellular spaces of the mesophyll and sub-stomatal cavity by $H$. rubrisubalbicans strain M1 which were surrounded by gum, strongly stained with toluidine blue (Figure 5c,d). In contrast to the wild type (M1), both $H$. rubrisubalbicans mutant strains were not frequently seen in different serial cross sections of the leaf blades. Although all the strains had the same pattern of mesophyll colonization described above (Figure 5c), TSE and TSN mutant strains colonized the leaf blade less extensively. Moreover, more plant gum was present, an indication of an effective host defense which apparently restricted the intercellular spreading of both mutants (Figure 5e). Interestingly, even in areas densely colonized by the mutants, the plant tissue showed only minor anatomic changes, preserving the shape and sizes of the parenchyma cells and vascular bundles (Figure 5e). However, the apoplastic colonization by the mutant strains reduced the numbers and sizes of the bundle sheath chloroplasts and produced changes in the cytoplasm and nuclei of plant host cells in close contact with the bacteria (Figure 5f, g). Taken together these results suggest that although the qualitative pattern of bacterial colonization was not affected, the T3SS is necessary for extensive colonization and to induce plant tissue changes which lead to mottled stripe disease symptoms.

H. rubrisubalbicans hrpE and $h r c N$ mutant strains do not elicit lesions on Vigna unguiculata leaves.

To study the effect of T3SS genes mutation in another host, $V$. unguiculata leaves were infiltrated with $H$. rubrisubalbicans strains M1, TSE and TSN. Inoculation with $H$. rubrisubalbicans M1 caused lesions on the leaves. The infiltrated zone showed the first sign of tissue collapse after $48 \mathrm{~h}$ of infiltration, and within 10 days the zone became necrotic, surrounded by strong chlorotic halos, followed by leaf loss (Figure 6b).

In contrast, infiltration of leaves with $H$. rubrisubalbicans TSE and TSN mutants did not produce lesions (Figure 6c, d). These data suggest that mutation in hrpE and $h r c N$ genes prevented the TSE and TSN mutant strains from causing disease symptoms on infiltrated leaves.

The leaves of $V$. unguiculata used as controls (Figure 5a) and those inoculated with the wild type M1 and mutant strains TSE and TSN were superficially disinfected, macerated and dilutions were plated. The results show that $10^{6}$ bacteria/g of fresh weight were

Table 1 Type III-effector proteins of $\boldsymbol{H}$. rubrisubalbicans

\begin{tabular}{cccc}
\hline Putative Effector Protein & Homology (Gene Bank accession number) & Identity/Similarity \% & Predicted size aa \\
\hline HropAV1 & type III effector, HopAV1 family [Ralstonia solanacearum] (CBJ40351.1) & $56 / 70$ & 784 \\
HropAN1 & type III effector Hrp-dependent outer protein [Burkholderia sp. Ch1-1] & $78 / 86$ & 428 \\
& (ZP_06844144.1) & $31 / 45$ & 643 \\
HropF1 & XopF1 effector [Xanthomonas oryzae pv. oryzae PXO99A] (YP_001911267.1) & $25 / 45$ & 736 \\
Hrop1 & type III effector protein (partial sequence central part) & $32 / 46$ & 641 \\
Hrop2 & [Ralstonia solanacearum MolK2] (YP_002252977.1) & &
\end{tabular}

The T3SS putative effectors were identified by BlastX and EffectiveT3 (http://www.effectors.org/) (Arnold et al., 2009). 


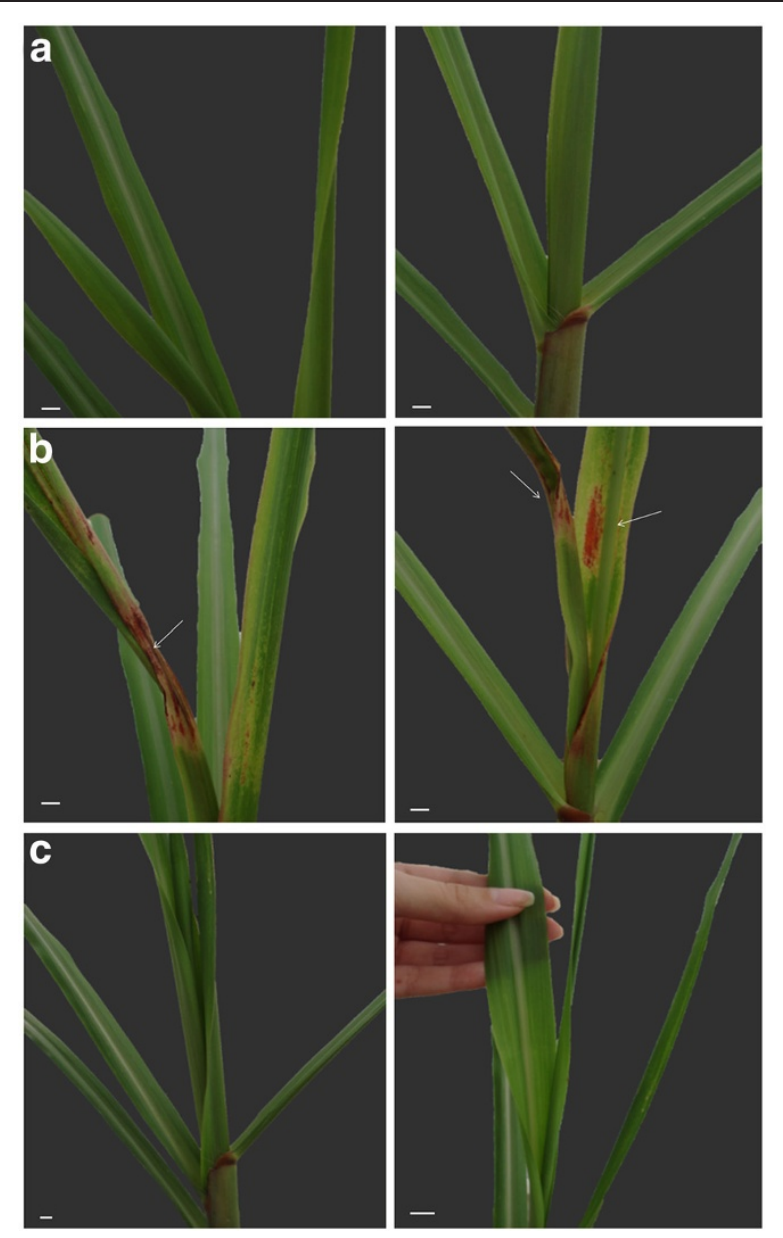

Figure 4 Inoculation of sugarcane variety B-4362 with wild type and hrpE mutant strains of H. rubrisubalbicans. 120 days after germination, 5 sugarcane plants variety B-4362 were inoculated

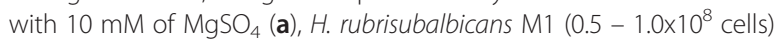
(b) and H. rubrisubalbicans TSE $\left(0.5-1.0 \times 10^{8}\right.$ cells) (c). The photos were taken 15 days after inoculation (135 days after germination). The arrows indicate bacterial inoculation site and symptoms of the mottled stripe disease (b). The scale bars are shown $(1 \mathrm{~cm})$.

recovered from leaves infiltrated with the wild type M1 (Figure 6e), while the number of bacteria from leaves infiltrated with mutant strains TSE and TSN was about 100 times lower (Figure 6e). The decrease in internal colonization is not due to differences in the growth rate since the doubling times of $H$. rubrisubalbicans T3SS mutant strains in NFbHPN medium are identical to the wild type (data not shown). When Pseudomonas syringae pv. tomato T3SS mutant strains were infiltrated in tomato leaves a reduction in the number of recovered bacteria was also observed $[35,36]$.

These results further support our findings that the genes $h r p E$ and $h r c N$ are involved in the colonization of $V$. unguiculata by $H$. rubrisubalbicans.

Mutations in $h r p E$ and $h r c N$ genes reduce the capacity of $H$. rubrisulbalbicans to colonize rice.
H. rubrisubalbicans has been found in roots and leaves of rice [37] but the interaction was not pathogenic. To investigate if $H$. rubrisubalbicans $h r c N$ and $h r p E$ genes are involved in such non-pathogenic endophytic colonization, rice seedlings were inoculated with $H$. rubrisubalbicans strains M1, TSE and TSN five days after germination and the number of endophytic bacteria determined 3, 5, 7 and 9 days after inoculation. No disease symptoms were observed in plants inoculated with any of these bacterial strains. Figure 7 shows that three days after inoculation the number of endophytic wildtype bacteria was 10 -fold higher than that of the mutant strains. This difference remained 5 and 7 days after inoculation and increased to 100 -fold after nine days. The results indicate that the genes $h r p E$ and $h r c N$ may also be involved in the endophytic colonization of rice by H. rubrisubalbicans.

\section{Discussion}

The type three secretion system of gram-negative plant pathogenic bacteria belonging to the genera Pseudomonas, Ralstonia, Xanthomonas and Erwinia is essential for disease development [35]. Bacteria of the genus Herbaspirillum endophytically colonize plants of the Poaceae family but can also be found in internal tissues of other plants such as Phaseolus vulgaris [38,39] and soybean (Glycine max) [40], as well as the tropical species banana and pineapple [41]. Most Herbaspirillum species establish neutral or beneficial interaction with plants [42-49]. H. rubrisubalbicans can establish non pathogenic beneficial interactions with the Poaceae but is also capable of causing disease in some varieties of sugarcane and sorghum $[1,2,5]$. In this report we show that the T3SS of $H$. rubrisubalbicans is important for establishing pathogenic interactions with sugarcane, lesion formation in $V$. unguiculata leaves as well as endophytic colonization of a rice cultivar and maize.

The gene organization of the H. rubrisubalbicans hrp/ $h r c$ cluster is identical to that of $H$. seropedicae [25]. The T3SS gene cluster of phytopathogenic bacteria can be divided into two groups based on DNA homology, genetic organization, and regulation pattern [35]. The structural organization of hrcUhrpXhrcShrcRhrcQ and hrpBhrcJhrpDhrpE genes in the H. rubrisubalbicans hrp cluster resembles that of bacteria such as Pseudomonas syringae, Erwinia amylovora, and Pantoea stewartii. $H$. rubrisubalbicans also possesses a $h r p L$ gene, a characteristic of bacteria from group I. The HrpL protein, a member of the ECF family of alternative sigma factors, regulates the expression of $h r p$ genes in group I [27,50,51]. Interestingly, H. rubrisubalbicans hrpL has no $\sigma^{54}$ promoter sequence, a feature conserved in group I organisms, but contains a gene highly similar to hrpG. The HrpG protein is involved in the expression of group 


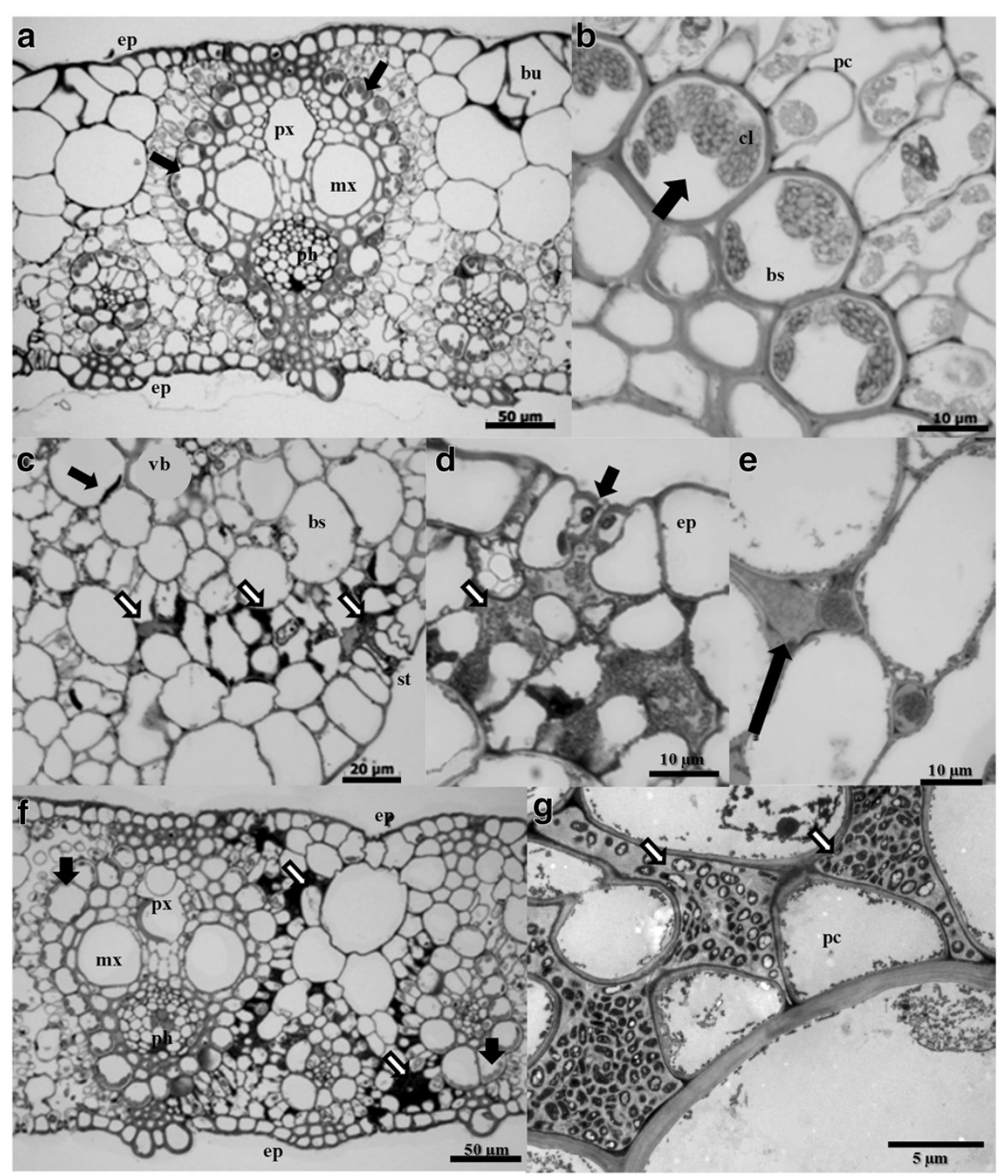

Figure 5 Light microscopy (LM) and transmission electron microscopy (TEM) of sugarcane leaf blades variety B-4362 inoculated with $\boldsymbol{H}$. rubrisubalbicans M1, TSE and TSN. (a) Transversal section showing the regular tissue organization of a control plant. (ep) epidermis layer, (px) protoxylem, (ph) phloem, (mx) metaxylem, (bu) buliform cells, (arrows) bundle sheath layer with healthy chloroplasts. (b) Detailed view of the bundle sheath layer (bs) showing its chloroplasts (cl) with regular shape, distribution and appearance (arrows), and (pc) parenchyma cells. (c) Typical pattern of colonization of H. rubrisubalbicans strain M1 (wild type) showing tissue system changes associated with extensive colonization of the intercellular spaces of the mesophyll and sub-stomatal cavity (white arrows). Note the chloroplast degradation (black arrow), (vb) vascular bundles, (bs) bundle sheath, (st) stomata. (d) Detailed view of the apoplastic colonization by the wild type M1 (white arrow) and beneath the stomata cavity (black arrow). Note the bacteria surrounded by toluidine blue-stained gums. (ep) epidermis. (e) Transversal section showing TSE and TSN mutants colonizing the leaf blade. Note the plant gums which restrict the intercellular spreading of the bacterial mutants (black arrow). (f) Transversal section of localized areas densely colonized by the mutants (white arrows) showing minor anatomical changes compared with panels (a) and (c). Note the reduced numbers and size of the bundle sheath chloroplasts (black arrow). (g) Transmission electron microscopy of the mutant bacteria colonizing the intercellular spaces of mesophyll cells. See changes in the cytoplasm of the plant host cell in close contact with the bacteria. (pc) parenchyma cells. Three plants of each condition were used for microscopy and the pictures are representative of the three inoculated plants.

II $h r p$ genes [52,53]. Upstream from orf1, orf6, hrpO, orf8, $h r p B$ and orf10 are conserved sequences that are similar to the hrp box sequences which are recognized by HrpL of $P$. syringae [27-29] suggesting the presence of at least six HrpL dependent operons. This is consistent with the observation that $h r p$ genes are commonly organized in large gene clusters, consisting of multiple transcriptional units. For instance, $P$. syringae pv. syringae and E. amylovora contain a $25 \mathrm{~Kb}$ cluster with eight transcriptional units [54].

Blast search using the available sequence allowed to identify five candidates for $H$. rubrisubalbicans effector 

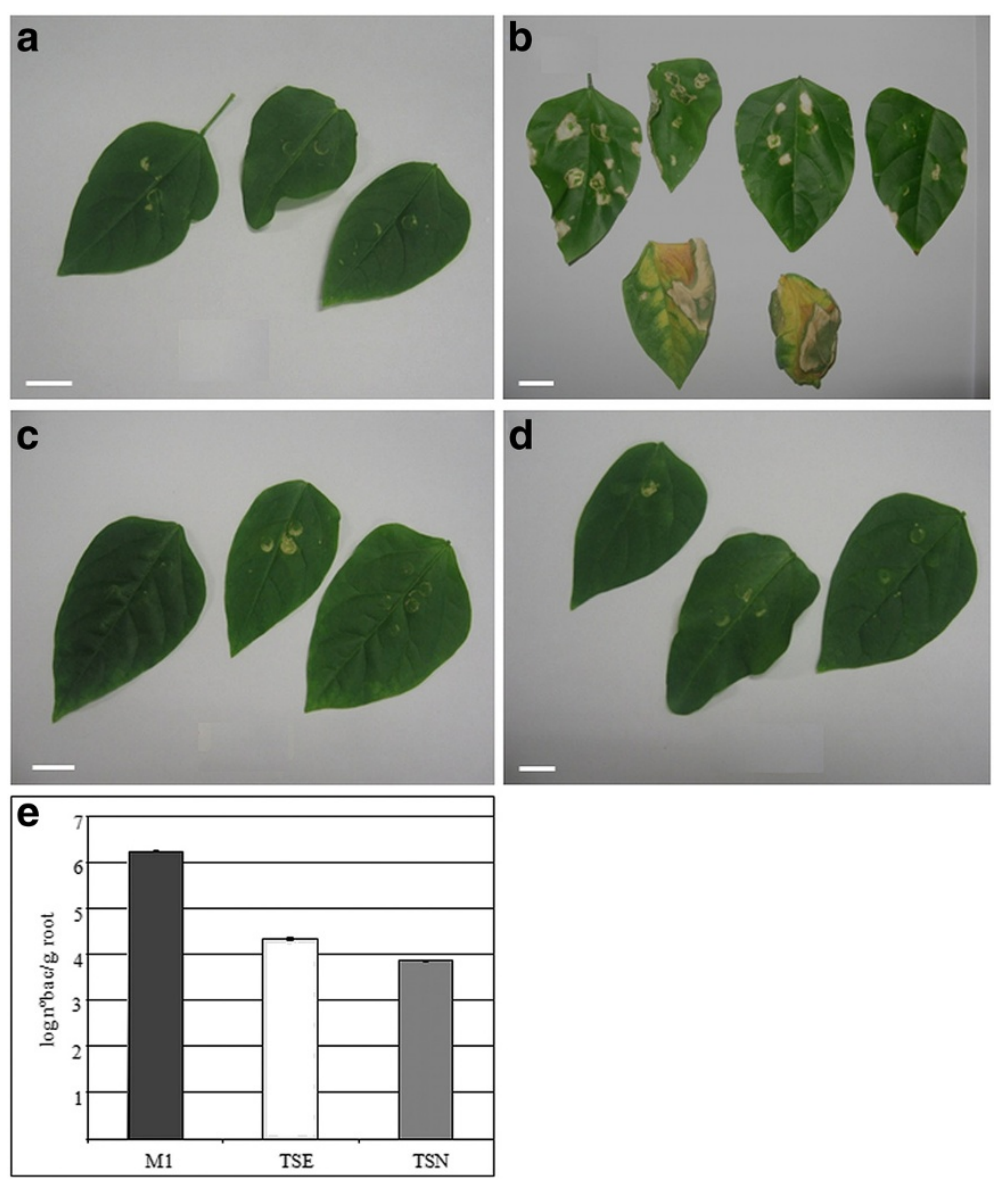

Figure 6 Inoculation of Vigna unguiculata leaves with M1, TSE and TSN strains of $H$. rubrisubalbicans and recovery of bacteria from internal tissue. $V$. unguiculata leaves were infiltrated twenty days after germination; the photos were taken 10 days after infiltration. The scale bars are shown $(1 \mathrm{~cm})$. (a) Control leaves were infiltrated with $1 \mathrm{~mL}$ of $\mathrm{MgSO}_{4} 10 \mathrm{mM}$ solution. (b) Leaves infiltrated with wild type strain M1 (108 cells). (c) Leaves infiltrated with $10^{8}$ cells of the mutant strain TSE. (d) Leaves infiltrated with mutant strain TSN (108 cells). (e) V. unguiculata plants were infiltrated with the indicated strains, and ten days later they were superficially disinfected, macerated, the macerate was diluted and plated. The plates were kept at $30^{\circ} \mathrm{C}$ for 24 hours and colonies counted. The experiment contained five plants in each condition and repeated on at least three separate dates. Results are shown as means of $\log _{10}$ (number of bacteria $\mathrm{g}^{-1}$ of fresh root). Standard deviation (Student $t$-test, $p<0.05)$.

proteins: Hrop1, Hrop2, HropAV1, HropAN1 and HropF1. Only HropAN1 has a counterpart in $H$. seropedicae, the other effector proteins are unique to $\mathrm{H}$. rubrisubalbicans and could be involved in the pathogenic phenotype of $H$. rubrisubalbicans.

To determine if the T3SS of $H$. rubrisubalbicans is functional we constructed and characterized $h r c N$ and $h r p E$ mutants. T3SS-associated ATPases (HrcN proteins) have long been predicted to be the key energizers of the T3SS. The $H$. rubrisubalbicans $h r c N$ mutant failed to cause the mottled stripe disease in sugarcane variety B4362, demonstrating that the $\mathrm{HrcN}$ of $\mathrm{H}$. rubrisubalbicans is important for bacterial pathogenicity. Similar results were observed in other plant pathogens, such as Xanthomonas oryzae pathovar oryzae KACC10859, whose $h r c N$ mutant completely lost virulence [55]. X. campestris pv. vesicatoria strain 85 , whose $h r c N$ mutant failed to induce plant reactions in susceptible and resistant pepper plants [56], and a $R$. solanacearum hrcN mutant lost virulence on tomato [57].

The $H$. rubrisubalbicans hrpE mutant also lost the ability to cause disease. This phenotype might be due to direct loss of the function of this gene or could be due to a polar effect on genes downstream from $h r p E$. For example, the gene $h r c C$, which expresses the poreforming outer membrane protein, is located downstream from $h r p E$ and without the pore the external needle effector proteins remain in the cytoplasm or periplasm of the bacteria. This phenotype has been shown for $P$. syringae, where the mutant strain in the $h r p E$ gene did not cause a hypersensitive response in plants of Nicotiana tabacum [33].

H. rubrisubalbicans $h r c N$ and $h r p E$ mutants did not elicit lesions on $V$. unguiculata leaves. Thus, our results 


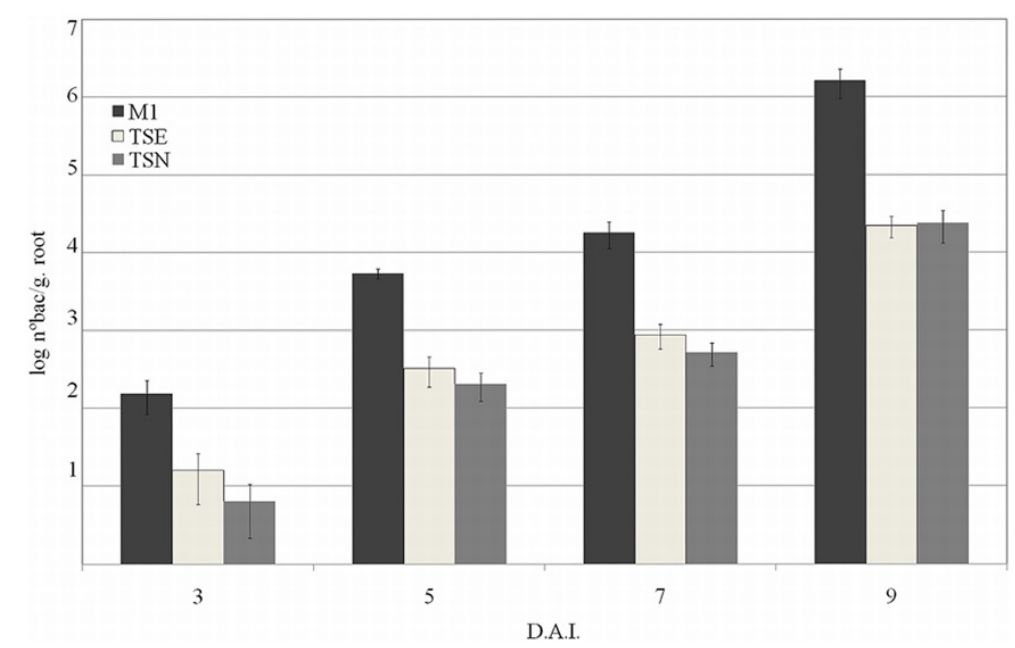

Figure 7 Internal colonization of Oryza sativa roots by $\boldsymbol{H}$. rubrisubalbicans. The number of endophytic bacteria colonizing internal rice root tissues was determined 3, 5, 7 and 9 days after inoculation (d.a.i.). The plants were superficially disinfected and the roots were cut, homogenized, diluted and plated. The plates were kept at $30^{\circ} \mathrm{C}$ for 24 hours and colonies counted. Results are shown as means of Log $_{10}$ (number of bacteria. $\mathrm{g}^{-1}$ of fresh root) \pm standard deviation (Student $t$-test; $P<0.05$ ). The experiment contained five different plants for each condition. This experiment was repeated on at least three separate dates.

point to the involvement of the $H$. rubrisubalbicans T3SS in the development of disease symptoms in $V$. unguiculata leaves.

Interestingly, the $H$. rubrisubalbicans $h r c N$ and $h r p E$ mutants were less proficient in endophytic colonization of rice and maize, indicating that the T3SS genes have a dual function depending on the host. In susceptible hosts T3SS expression by $H$. rubrisubalbicans leads to the development of disease whereas in symptomless hosts the T3SS is important to avoid the plant response allowing bacterial colonization. Impairment of the T3SS system also produced opposing effects on different plants inoculated with the symbiotic nodulating bacterium Rhizobium sp. NGR234 [58]. Some leguminous plants are more effectively nodulated by an $r h c N$ ( $h r c N$ homolog) mutant strain than by the wild type, while others display the opposite behavior. Molecular analysis of this behavior lead to the characterization of effector proteins as being positive, negative or neutral depending on the effect of their removal [59]. Since H. rubrisubalbicans strains can stimulate growth of some plants [8] it remains to be determined if the T3SS of such strains can contribute to the beneficial effects.

\section{Conclusions}

Our results showed that a mutation in the $h r p E$ and $h r c N$ genes lead to a bacterium uncapable to cause the mottled stripe disease in B-4362 sugarcane, indicating that the $H$. rubrisubalbicans T3SS is necessary for the development of the disease. A decrease in rice endophytic colonization was also observed with these mutants, suggesting that in symptomless plants the $H$. rubrisubalbicans T3SS is important for endophytic colonization.

\section{Methods}

\section{Bacterial strains}

The bacterial strains used in this study are listed in Table 2.

\section{Media and growth conditions}

Escherichia coli was grown at $37^{\circ} \mathrm{C}$ in $\mathrm{LB}$ medium [60]. Strains of $H$. rubrisubalbicans were grown at $30^{\circ} \mathrm{C}$ in NFbHPN-malate [61]. Antibiotics were used at the following concentrations: tetracycline $10 \mu \mathrm{g} \mathrm{ml}^{-1}$, ampicillin $250 \mu \mathrm{g} \mathrm{ml} \mathrm{g}^{-1}$, chloramphenicol $30 \mu \mathrm{g} \mathrm{ml} \mathrm{m}^{-1}$, and kanamycin $50 \mu \mathrm{g} \mathrm{ml}^{-1}$ for E. coli strains and $100 \mu \mathrm{g} \mathrm{ml}^{-1}$ for $H$. rubrisubalbicans strains.

\section{H. rubrisubalbicans hrp/hrc genes sequencing}

Partial sequencing of the $H$. rubrisubalbicans M1 genome (Monteiro et al., unpublished) revealed the presence of T3SS genes. $h r p / h r c$ gene specific primers were designed to amplify and sequence gaps to obtain the whole sequence of the T3SS gene cluster. DNA sequence reactions were analyzed with an ABI PRISM 377 automatic DNA sequencer (Applied Biosystems, California, USA).

\section{Phylogenetic analyses}

Phylogenetic and molecular evolutionary analyses were conducted using MEGA version 5 [62]. DNA sequences were retrieved from GenBank database, translated to amino acids sequences and aligned using Muscle [63] 
Table 2 Bacterial strains

\begin{tabular}{|c|c|c|}
\hline Strains & Genotype/phenotype & Reference \\
\hline $\begin{array}{c}\text { Herbaspirillum } \\
\text { rubrisubalbicans M1 }\end{array}$ & Wild type strain & (BALDANl et al., 1996) \\
\hline $\begin{array}{c}\text { Herbaspirillum } \\
\text { rubrisubalbicans TSE }\end{array}$ & M1 hrpE EZ:: $\mathrm{Tn} 5^{\mathrm{TM}}<\mathrm{TET} 1>, \mathrm{Tc}^{\mathrm{R}}, \mathrm{Km}^{\mathrm{R}}$ & This work \\
\hline $\begin{array}{l}\text { Herbaspirillum } \\
\text { rubrisubalbicans TSN }\end{array}$ & M1 hrcN EZ::Tn5 ${ }^{\mathrm{TM}}<\mathrm{TET} 1>$, Tc ${ }^{\mathrm{R}}$ & This work \\
\hline $\begin{array}{c}\text { Escherichia coli } \\
\text { TOP10 }\end{array}$ & $\begin{array}{c}\mathrm{F}^{-} \text {mcrA } \Delta(\text { mcrr-hsdRMS-mcrBC) } \varphi 80 \text { lacZZMM15 } \\
\Delta \text { lacZX74 doeR recA1 endA1 ara } \Delta 139 \Delta \text { (ara, leu) } \\
7697 \text { galU galK } \lambda^{-} \text {rpsL nupG } \lambda^{-}\end{array}$ & INVITROGEN \\
\hline
\end{tabular}

with the following option differing from default: gap opening -12 , gap extension -1 , and hydrophobicity multiplier 1. Redundancy for sequences showing less than $0.1 \mathrm{p}$-distances were eliminated to avoid any bias, then the remaining sequences were realigned. Aligned amino acids sequences were converted back to nucleotide sequences and used to perform phylogenetic analysis. Alignment of protein sequences allow the use of substitution matrix and avoid gap insertion within codons. The Maximum Likelihood (ML) method was used to test the evolutionary models giving best results with Tamura 3-parameters, with gamma-distribute rates and invariant sites model. The selected model was used to build a phylogenetic tree using the ML method with 1,000 bootstrap replicates. Option for partial deletion with site coverage of $95 \%$ and a phylogenetic tree built using Neighbor-Joining (NJ) method with Kimura 2parameter calculated distances and 10,000 bootstrap replicates was used as a start tree for all ML analysis.

Edition in phylogenetic tree was made using FigTree version 1.3.1 (http://tree.bio.ed.ac.uk/).

\section{Plant assays}

Bacterial cultures of $H$. rubrisubalbicans $\mathrm{M} 1$ were grown in NFbHPN-malate [61] medium at $30^{\circ} \mathrm{C}$ for $18 \mathrm{~h}$ with shaking (120 rpm).

Sugarcane variety B-4362 cuttings were obtained from the Program for Genetic Improvement of Sugarcane CECA/UFAL. These were surface disinfected by treatment with Karate $0.1 \%$ and Derosal $0.01 \%$ for 2 minutes and heat treatment (immersion in water at $52^{\circ} \mathrm{C}$ for $30 \mathrm{~min}$ utes). Sugarcane inoculation was performed as described [1]. 120 days after germination the stalks of sugarcane were inoculated by injecting with a hypodermic syringe 0.5 to $1 \mathrm{~mL}$ of cell suspension in $10 \mathrm{mM} \mathrm{MgSO}_{4}$ $\left(10^{8} \mathrm{cfu} \mathrm{mL}^{-1}\right)$ into the foliar cartridge 2 to $3 \mathrm{~cm}$ below the first leaf. After inoculation the leaves were pruned halfway, and the plant was wrapped with a plastic bag to maintain a high humidity environment. Sugarcane inoculated with $H$. rubrisubalbicans was visually inspected for mottled stripe disease 15 days after inoculation. Vigna unguiculata cultivar Red Caloona seeds were sterilized with $97 \%$ sulfuric acid for 10 minutes, followed by four washes with sterilized water [64]. The seeds were germinated in pots containing vermiculite and $\mathrm{BD}$ nutrient solution [65] and cultivated at $30^{\circ} \mathrm{C}$ with a $16 \mathrm{~h}$ light period.

Bacterial suspensions $\left(10^{8} \mathrm{cfu} \mathrm{mL}^{-1}\right)$ in $10 \mathrm{mM}$ $\mathrm{MgSO}_{4}$ were infiltrated into the abaxial leaf surface of twenty days old $V$. unguiculata using a syringe without a needle. The plants were kept in a greenhouse at $30^{\circ} \mathrm{C}$, illuminated by sunlight and watered every three days. To determine the number of endophytic bacteria, ten days after $H$. rubrisubalbicans infiltration, leaves were superficially disinfected with $70 \%$ ethanol for five minutes, washed with sterilized water and homogenized with a sterile pestle and mortar in $1 \mathrm{~mL}$ of sterile PBS. Leaf extracts were serially diluted and used to determine the number of bacteria colonizing internal plant tissues by plating on NFbHPN-malate.

Oryza sativa L. ssp. japonica seeds (variety BRS Formosa) were surface-sterilized with ethanol $70 \%$ for $1 \mathrm{~min}$ then shaken in $6 \%$ hypochlorite and $0.02 \%$ tween 20 for $30 \mathrm{~min}$ at $30^{\circ} \mathrm{C}$, and washed three times with sterile water. The seeds were germinated in Petri dishes containing 1\% agar at $25^{\circ} \mathrm{C}$ for $120 \mathrm{~h}$. Plants were grown in an incubator at $25^{\circ} \mathrm{C}$ with a $16 \mathrm{~h}$ light period and $60 \%$ humidity. Thirty seedlings were inoculated five days after germination with $30 \mathrm{~mL}$ of $H$. rubrisubalbicans strains suspension $\left(10^{8} \mathrm{cfu} \mathrm{mL}^{-1}\right)$ by immersion for 15 minutes. The seedlings were transferred to glass tubes containing $20 \mathrm{~mL}$ of Hoagland medium [66] with $0.2 \%$ agar and maintained at $25^{\circ} \mathrm{C}, 16 \mathrm{~h}$ light period. The roots were cut $3,5,7$ and 9 days after inoculation, weighed before surface sterilization by a 2 minutes wash with $1 \%$ sodium hypochlorite containing $0.01 \%$ tween-20, followed by 2 minutes in $70 \%$ ethanol, and four washes with sterile distilled water. The samples were then homogenized using a sterile pestle and mortar, and the root extracts diluted in $1 \mathrm{~mL}$ of sterile PBS. The number of bacteria colonizing internal plant tissues was determined by plating several dilutions of the extracts on NFbHPN-malate plates. The results reported here represent the average of at least five independent experiments. 


\section{Recombinant DNA techniques}

Standard procedures were performed for plasmid DNA extraction, restriction enzyme reactions, cloning and bacterial transformations [60 or according to the manufactures recommendations].

\section{Construction of $H$. rubrisubalbicans $h r p E$ and $h r c N$ mutant strains}

The genes $h r p E$ and $h r c N$ of $H$. rubrisubalbicans in plasmids HR02-MF-00-000-009-C05.km and HR02MF-00-000-053-F11.km (Monteiro and Petruzziello, unpublished) were disrupted by the transposon EZ:: $\mathrm{Tn} 5^{\mathrm{TM}}<\mathrm{TET} 1>$ (Epicentre) that confers resistance to tetracycline. The mutant suicide plasmids were electroporated into the wild type $H$. rubrisubalbicans strain M1. Recombinant cells were selected for tetracycline resistance and screened for the loss of kanamycin resistance (vector marker). Southern blot analyses of EcoRI digested genomic DNA were used to confirm the presence of the tetracycline transposon in $h r p E$ and $h r c N$. (data not shown). The selected mutant strains, named TSE and TSN, contained transposon insertions into $h r p E$ and $h r c N$, respectively.

\section{Light and transmission electron microscopy}

Leaves were taken at 21 days after inoculation, washed twice in phosphate buffer $(50 \mathrm{mM}, \mathrm{pH} 7.0)$ and fixed in $2.5 \%(\mathrm{v} / \mathrm{v})$ glutaraldehyde (in $50 \mathrm{mM}$ phosphate buffer, $\mathrm{pH}$ 7.0). Leaf sections were prepared for light and transmission electron microscopy according to James et al. [67].

\section{Additional file}

Additional file 1: Table S1. Aminoacids sequence homology between $\mathrm{Hrp} / \mathrm{Hrc}$ proteins of $\mathrm{H}$. rubrisubalbicans and $H$. seropedicae. These data show the identity and similarity between the T3SS proteins from $\mathrm{H}$. rubrisubalbicans and $\mathrm{H}$. seropedicae.

\section{Authors' contributions}

Conceived and designed the work: FOP, RAM and EMS. Performed the experiments: MAS, EB, RW, HF, FLO and VAB. Performed assembly, annotation, and bioinformatics analyses: MAS, EB, RW, LMC, VAW, HF, EMS, RAM, HMFM, LPF, MHPF, FMP, LFPP, LGEC. Wrote the manuscript: RAM, EMS, MGY and MAS. Prepared figures: LMC, RAM, EB and MAS. All authors read and approved the final manuscript.

\section{Acknowledgements}

This work was supported by the Brazilian agencies CAPES and INCT-FBN/ CNPq. The authors thank Roseli Prado and Julieta Pie for technical assistance.

\section{Author details}

${ }^{1}$ Department of Biochemistry and Molecular Biology, Universidade Federal do Paraná, R. Francisco H. dos Santos s/n, Curitiba 81531-990, Brazil.

${ }^{2}$ Department of Genetics, Universidade Federal do Paraná, R. Francisco H. dos Santos s/n, Curitiba 81531-990, Brazil. ${ }^{3}$ Center for Agricultural and Environmental Sciences, Pontifícia Universidade Católica do Paraná, Rua Imaculada Conceição, 1155, Curitiba 80215-901, Brazil. ${ }^{4}$ Department of General Biology, Universidade Estadual de Londrina, Rodovia Celso Garcia Cid PR-445 Km 380, Londrina 86051-990, Brazil. ${ }^{5}$ Departament of Genetics and Molecular Biology, Instituto Agronômico do Paraná, Rodovia Celso
Garcia Cid Km 375, Londrina 86047-902, Brazil. ${ }^{6}$ Center of Bioscience and Biotechnology, Universidade Estadual do Norte Fluminense/CBB/LBCT, Av. Alberto Lamego, 2000, Campos dos Goytacazes 28013-600, Brazil.

Received: 30 November 2011 Accepted: 24 April 2012

Published: 6 June 2012

\section{References}

1. Olivares FL, James EK, Baldani Jl, Dobereiner J: Infection of mottled stripe disease-susceptible and resistant sugar cane varieties by the endophytic diazotroph Herbaspirillum. New Phytol 1997, 135:723-737.

2. James EK, Olivares FL: Infection and colonization of sugarcane and other graminaceous plants by endophytic diazotrophs. Crit Rev Plant Sci 1998, 17:77-119.

3. Pimentel JP, Olivares FL, Pitard RM, Urquiaga S, Akiba F, Döbereiner J: Dinitrogen fixation and infection of Grass leaves by Pseudomonas rubrisubalbicans and Herbaspirillum seropedicae. Plant Soil 1991, 137:61-65.

4. Hale CN, Wilkie JP: A comparative study of Pseudomonas species pathogenic to sorghum. New Zeal J Agr Res 1972, 15:448-456.

5. James EK, Olivares FL, Baldani Jl, Dobereiner J: Herbaspirillum, an endophytic diazotroph colonizing vascular tissue in leaves of Sorghum bicolor L. Moench. J Exp Bot 1997, 48:785-797.

6. Christopher WN, Edgerton CW: Bacterial stripe diseases of sugarcane in Louisiana. J Agric Res 1932, 41:259-267.

7. Oliveira ALM, Urquiaga S, Döbereiner J, Baldani Jl: The effect of inoculating endophytic N2-fixing bacteria on micropropagated sugarcane plants. Plant Soil 2002, 242:205-215.

8. Oliveira ALM, Canuto EL, Urquiaga S, Reis VM, Baldani J: Yield of micropropagated sugarcane varieties in different soil types following inoculation with diazotrophic bacteria. Plant Soil 2006, 284:23-32.

9. Oliveira ALM, Stoffels M, Schmid M, Reis VM, Baldani Jl, Hartmann A: Colonization of sugarcane plantlets by mixed inoculations with diazotrophic bacteria. Eur J Soil Biol 2009, 45:106-111.

10. Reis VM, Oliveira ALMM, da Silva F, Olivares FL, Baldani Jl, Boddey RM, Urquiaga S: Inoculants for Sugar Cane: The Scientific Bases for the Adoption of the Technology for Biofuel Production. Biological Nitrogen Fixation: Towards Poverty Alleviation through Sustainable Agriculture. Curr Plant Sci Biotechnol Agric 2008, 42:67-68.

11. Lindgren PB, Peet RC, Panopoulos NJ: Gene cluster of Pseudomonas syringae pv. phaseolicola controls pathogenicity of bean plants and hypersensitivity on nonhost plants. J Bacteriol 1986, 168:512-522.

12. Knoop V, Staskawicz B, Bonas U: Expression of the avirulence gene avrBs3 from Xanthomonas campestris pv. vesicatoria is not under the control of hrp genes and is independent of plant factors. J Bacteriol 1991, 173:7142-7150.

13. Huang J, Schell M: Molecular characterization of the eps gene cluster of Pseudomonas solanacearum and its transcriptional regulation at a single promoter. Mol Microbiol 1995, 16:977-989.

14. Kim JF, Wei ZM, Beer SV: The hrpA and hrpC operons of Erwinia amylovora encode components of a type III pathway that secretes harpin. J Bacteriol 1997, 179:1690-1697.

15. Fenselau S, Balbo I, Bonas U: Determinants of pathogenicity in Xanthomonas campestris pv. vesicatoria are related to proteins involved in secretion in bacterial pathogens of animals. Mol Plant Microbe In 1992, 5:390-396.

16. Gough CL, Genin S, Zischek C, Boucher CA: hrp genes of Pseudomonas solanacearum are homologous to pathogenicity determinants of animal pathogenic bacteria and are conserved among plant pathogenic bacteria. Mol Plant Microbe In 1992, 5:384-389.

17. Bogdanove AJ, Wei ZM, Zhao L, Beer SV: Erwinia amylovora secretes harpin via a type III pathway and contains a homolog of yop $N$ of Yersinia spp. J Bacteriol 1996, 178:1720-1730.

18. Viprey V, Del Greco A, Golinowski W, Broughton WJ, Perret X: Symbiotic implications of type III protein secretion machinery in Rhizobium. Mol Microbiol 1998, 28:1381-1389.

19. Hacker J, Carniel E: Ecological fitness, genomic islands and bacterial pathogenicity. EMBO Rep 2001, 2:376-381

20. Mota LJ, Sorg I, Cornelis GR: Type III secretion: The bacteria-eukaryotic cell express. FEMS Microbiol Lett 2005, 252:1-10. 
21. Grant SR, Fisher EJ, Chang JH, Mole BM, Dangl JL: Subterfuge and manipulation: type III effector proteins of phytopathogenic bacteria. Ann Rev Microbiol 2006, 60:425-449.

22. Cornelis GR, van Gijsegem F: Assembly and function of type III secretory systems. Ann Rev Microbiol 2000, 54:735-774.

23. Hendrickson EL, Guevera P, Ausubel FM: The alternative sigma factor RpoN is required for hrp activity in Pseudomonas syringae pv. maculicola and acts at the level of hrpL transcription. J Bacterio/ 2000 182:3508-3516.

24. Tang $X$, Xiao $Y$, Zhou JM: Regulation of the type iii secretion system in phytopathogenic bacteria. Mol Plant Micobe In 2006 19:1159-1166.

25. Pedrosa FO, Monteiro RA, Wassem R, Cruz LM, Ayub RA, Colauto NB, Fernandez MA, Fungaro MH, Grisard EC, Hungria M, Madeira HM, Nodari RO, Osaku CA, Petzl-Erler ML, Terenzi H, Vieira LG, Steffens MB, Weiss VA, Pereira LF, Almeida MI, Alves LR, Marin A, Araujo LM, Balsanelli E, Baura VA, Chubatsu LS, Faoro H, Favetti A, Friedermann G, Glienke C, Karp S, KavaCordeiro V, Raittz RT, Ramos HJ, Ribeiro EM, Rigo LU, Rocha SN, Schwab S, Silva AG, Souza EM, Tadra-Sfeir MZ, Torres RA, Dabul AN, Soares MA, Gasques LS, Gimenes CC, Valle JS, Ciferri RR, Correa LC, Murace NK, Pamphile JA, Patussi EV, Prioli AJ, Prioli SM, Rocha CL, Arantes OM, Furlaneto MC, Godoy LP, Oliveira CE, Satori D, Vilas-Boas LA, Watanabe MA, Dambros BP, Guerra MP, Mathioni SM, Santos KL, Steindel M, Vernal J, Barcellos FG, Campo RJ, Chueire LM, Nicolás MF, Pereira-Ferrari L, Silva JL, Gioppo NM, Margarido VP, Menck-Soares MA, Pinto FG, Simão Rde C, Takahashi EK, Yates MG, Souza EM: Genome of Herbaspirillum seropedicae strain SmR1, a specialized diazotrophic endophyte of tropical grasses. PLoS Genet 2011, 7:e1002064.

26. Xiao Y, Heu S, Yi J, Lu Y, Hutcheson SW: Identification of a putative alternate sigma factor and characterization of a multicomponent regulatory cascade controlling the expression of Pseudomonas syringae pv. syringae Pss61 hrp and hrmA genes. J Bacteriol 1994, 176:1025-1036.

27. Wei ZM, Beer SV: hrpL activates Erwinia amylovora hrp gene transcription and is a member of the ECF subfamily of sigma factors. J Bacteriol 1995, 177:6201-6210.

28. Fouts DE, Abramovitch RB, Alfano JR, Baldo AM, Buell CR, Cartinhour S, Chatterjee AK, D'Ascenzo M, Gwinn ML, Lazarowitz SG, Lin NC, Martin GB, Rehm AH, Schneider DJ, van Dijk K, Tang X, Collmer A: Genomewide identification of Pseudomonas syringae pv. tomato DC3000 promoters controlled by the HrpL alternative sigma factor. P Natl Acad Sci USA 2002, 19:2275-2280.

29. Ferreira AO, Myers CR, Gordon JS, Martin GB, Vencato M, Collmer A, Wehling MD, Alfano JR, Moreno-Hagelsieb G, Lamboy WF, DeClerck G, Schneider DJ, Cartinhour SW: Whole-genome expression profiling defines the HrpL regulon of Pseudomonas syringae pv. tomato DC3000, allows de novo reconstruction of the Hrp cis clement, and identifies novel coregulated genes. Mol Plant Microbe In 2006, 19:1167-1179.

30. Buttner D, Gurlebeck D, Noel LD, Bonas U: HpaB from Xanthomonas campestris pv. vesicatoria acts as an exit control protein in type IIIdependent protein secretion. Mol Microbiol 2004, 54:755-768.

31. Arnold R, Brandmaier S, Kleine F, Tischler P, Heinz E, Behrens S, Niinikoski A, Mewes HW, Horn M, Rattei T: Sequence-based prediction of type III secreted proteins. PLoS Pathog 2009, 5:e1000376.

32. Marchler-Bauer A, Anderson JB, Chitsaz F, Derbyshire MK, DeWeese-Scott C, Fong JH, Geer LY, Geer RC, Gonzales NR, Gwadz M, He S, Hurwitz DI, Jackson JD, Ke Z, Lanczycki CJ, Liebert CA, Liu C, Lu F, Lu S, Marchler GH, Mullokandov M, Song JS, Tasneem A, Thanki N, Yamashita RA, Zhang D, Zhang N, Bryant SH: CDD: specific functional annotation with the Conserved Domain Database. Nucleic Acids Res 2009, 37:205-210.

33. Ramos AR, Morello JE, Ravindran S, Deng WL, Huang HC, Collmer A: Identification of Pseudomonas syringae pv. syringae 61 type III secretion system Hrp proteins that can travel the type III pathway and contribute to the translocation of effector proteins into plant cells. J Bacteriol 2007, 189:5773-5778.

34. Gazi AD, Bastaki M, Charova SN, Gkougkoulia EA, Kapellios EA, Panopoulos $\mathrm{NJ}$, Kokkinidis M: Evidence for a coiled-coil interaction mode of disordered proteins from bacterial type III secretion systems. J Biol Chem 2008, 49:34062-34068.
35. Alfano JR, Collmer A: The type III (Hrp) secretion pathway of plant pathogenic bacteria: trafficking harpins, Avr proteins and death. J Bacteriol 1997, 179:5655-5662.

36. Badel JL, Shimizu R, Oh HS, Collmer A: A Pseudomonas syringae pv. tomato avrE1/hopM1 mutant is severely reduced in growth and lesion formation in tomato. Mol Plant Microbe In 2006, 2:99-111.

37. Baldani Jl, Pot B, Kirchhof G, Falsen E, Baldani VL, Olivares FL, Hoste B, Kersters K, Hartmann A, Gillis M, Döbereiner J: Emended description of Herbaspirillum, a mild plant pathogen, as Herbaspirillum rubrisubalbicans comb. nov., and classification of a group of clinical isolates (EF group 1) as Herbaspirillum species 3. Int J Sys Bacteriol 1996, 46:802-810.

38. Valverde A, Velazquez E, Gutierrez C, Cervantes E, Ventosa A, Igual JM: Herbaspirillum lusitanum sp. nov., a novel nitrogen-fixing bacterium associated with root nodules of Phaseolus vulgaris. J Syst Evol Microbiol 2003, 53:1979-1983.

39. Schmidt MA, Souza EM, Baura V, Wassem R, Yates MG, Pedrosa FO, Monteiro RA: Evidence for the endophytic colonization of Phaseolus vulgaris (common bean) roots by the diazotroph Herbaspirillum seropedicae. Braz $J$ Med Biol Res 2011, 44:182-185.

40. Kuklinsky-Sobral J, Araújo WL, Mendes R, Geraldi IO, Pizzirani-Kleiner AA, Azevedo JL: Isolation and characterization of soybean-associated bacteria and their potential for plant growth promotion. Environ Microbiol 2004, 6:1244-1251.

41. Cruz LM, Souza EM, Weber OB, Baldani Jl, Döbereiner J, Pedrosa FO: $16 \mathrm{~S}$ ribosomal DNA characterization of nitrogen-fixing bacteria isolated from banana (Musa spp.) and pineapple (Ananas comosus (L.) Merril). Appl Environ Microb 2001, 67:2375-2379.

42. Baldani Jl, Baldani VL: History on the biological nitrogen fixation research in graminaceous plants: special emphasis on the Brazilian experience. An Acad Bras Cienc 2005, 77:549-579.

43. Gyaneshwar P, James EK, Reddy PM, Ladha JK: Herbaspirillum colonization increases growth and nitrogen accumulation in aluminium-tolerant rice varieties. New Phitol 2006, 154:131-145.

44. James EK, Gyaneshwar P, Mathan N, Barraquio WL, Reddy PM, lannetta PPM, Olivares FL, Ladha JK: Infection and colonization of rice seedlings by the plant growth-promoting bacterium Herbaspirillum seropedicae Z67. Mol Plant Microbe In 2002, 15:894-906.

45. Roncato-Maccari LDB, Ramos HJO, Pedrosa FO, Alquini Y, Chubatsu LS, Yates MG, Rigo LU, Steffens MBR, Souza EM: Endophytic Herbaspirillum seropedicae expresses nif genes in gramineous plants. FEMS Microbiol Ecol 2003, 45:39-47.

46. Elbeltagy A, Nishioka K, Sato T: Endophytic colonization and in plant nitrogen fixation by a Herbaspirillum sp. Isolated from wild rice species. Appl Environ Microbiol 2001, 67:5285-5293.

47. Rothballer M, Schmid M, Klein I, Gattinger A, Grundmann S, Hartmann A: Herbaspirillum hiltneri sp. nov., isolated from surface-sterilized wheat roots. In J Syst Evol Microb 2006, 56:1341-1348.

48. Jung SY, Lee MA, Oh TK, Yoon JH: In J Syst Evol Micr 2007, 57:2284-2288.

49. Rothballer M, Eckert B, Schmid M, Fekete A, Schloter M, Lehner A, Pollmann S, Hartmann A: Endophytic root colonization of gramineous plants by Herbaspirillum frisingense. FEMS Microbiol Ecol 2008, 66:85-95.

50. Xiao $Y, L U Y$, Heu S, Hutcheson SW: Organization and environmental regulation of the Pseudomonas syringae pv. syringae $61 \mathrm{hrp}$ cluster. J Bacteriol 1992, 174:1734-1741.

51. Frederick RD, Ahmad M, Majerczak DR, Arroyo-Rodríguez AS, Manulis S, Coplin DL: Genetic organization of the Pantoea stewartii subsp. stewartii hrp gene cluster and sequence analysis of the $h r p A, h r p C, h r p N$, and wtsE operons. Mol Plant Microbe 2001, 14:1213-1222.

52. Wengelnik K, Van den Ackerveken G, Bonas U: HrpG, a key hrp regulatory protein of Xanthomonas campestris pv. vesicatoria is homologous to two-component response regulators. Mol Plant Microbe In 1996, 9:704-712.

53. Brito B, Marenda M, Barberis P, Boucher C, Genin S: prhJ and hrpG, two new components of the plant signal-dependent regulatory cascade controlled by PrhA in Ralstonia solanacearum. Mol Microbiol 1999, 31:237-251.

54. Lindgren PB: The role of hrp genes during plant-bacterial interactions. Ann Rev Phytopathol 1997, 35:129-152.

55. Cho HJ, Park YJ, Noh TH, Kim YT, Kim JG, Song ES, Lee DH, Lee BM: Molecular analysis of the hrp gene cluster in Xanthomonas oryzae pathovar oryzae KACC10859. Microb Pathogenesis 2008, 44:473-483. 
56. Lorenz C, Büttner D: Functional characterization of the type III secretion ATPase HrcN from the plant pathogen Xanthomonas campestris pv. vesicatoria. J Bacterio/ 2009, 191:1414-1428.

57. van Gijsegem F, Vasse J, de Rycke R, Castello P, Boucher C: Genetic dissection of Ralstonia solanacearum hrp gene cluster reveals that the HrpV and HrpX proteins are required for Hrp pilus assembly. Mol Microbiol 2002, 44:935-946.

58. Marie C, Broughton WJ, Deakin WJ: Rhizobium type III secretion systems: legume charmers or alarmers? Curr Opin Plant Biol 2001, 4:336-342.

59. Kambara K, Ardissone S, Kobayashi H, Saad MM, Schumpp O, Broughton WJ, Deakin WJ: Rhizobia utilize pathogen-like effector proteins during symbiosis. Mol Microbiol 2009, 71:92-106.

60. Sambrook J, Fritsch EF, Maniatis T: Molecular cloning: a laboratory manual. Cold Spring Harbor: Cold Spring Harbor Laboratory Press; 1989.

61. Klassen G, Pedrosa FO, Souza EM, Funayama S, Rigo LU: Effect of nitrogen compounds on nitrogenase activity in Herbaspirillum seropedicae SMR1. Can J Bacteriol 1997, 43:887-891.

62. Tamura K, Peterson D, Peterson N, Stecher G, Nei M, Kumar S: MEGA5: molecular evolutionary genetics analysis using likelihood, distance, and parsimony methods. Mol Biol Evol 2011, 28:2731-2739.

63. Edgar RC: MUSCLE: multiple sequence alignment with high accuracy and high throughput. Nucleic Acids Res 2004, 32:1792-1797.

64. Skorpil P, Saad MM, Boukli NM, Kobayashi H, Ares-orpel F, Broughton WJ, Deakin WJ: Nop, a phosphorylated effector of Rhizobium sp. strain NGR234, is a major determinant of nodulation of the tropical legumes Flemingia congesta and Tephrosia vogelii. Mol Microbiol 2005, 57:1304-1317.

65. Broughton WJ, Dilworth MJ: Control of leghaemoglobin synthesis in snake beans. Biochem J 1971, 125:1075-1080.

66. Hoagland D, Arnon DI: The water culture method for growing plants without soil. California Agriculture Experimental Station Circular 1950, 347:1-32.

67. James EK, Olivares FL, Baldani Jl, Dobereiner J: Herbaspirillum, an endophytic diazotroph colonizing vascular tissue in leaves of Sorghum bicolor L. Moench J Exp Bot 1996, 48:785-797.

\section{doi:10.1186/1471-2180-12-98}

Cite this article as: Schmidt et al:: The type III secretion system is necessary for the development of a pathogenic and endophytic interaction between Herbaspirillum rubrisubalbicans and Poaceae. BMC Microbiology 2012 12:98.

\section{Submit your next manuscript to BioMed Central and take full advantage of:}

- Convenient online submission

- Thorough peer review

- No space constraints or color figure charges

- Immediate publication on acceptance

- Inclusion in PubMed, CAS, Scopus and Google Scholar

- Research which is freely available for redistribution 